\title{
RENUNGAN EKOTEOLOGIS \\ KH. KPP. NOER NASROH HADININGRAT DI PESANTREN WALISONGO TUBAN
}

\author{
Fikri Mahzumi \\ Universitas Islam Negeri Sunan Ampel Surabaya, Indonesia \\ E-mail: fikrimuz@gmail.com
}

\begin{abstract}
This article is an attempt to describe the theological paradigm of environment existing in Pesantren Walisongo Tuban. From an academic perspective, this paradigm is often regarded as eco-theology. This discourse has been widely discussed by many experts and activists of environment from different countries as new attempts to cope with global crisis faced by human being. KH KPP Noer Nasroh Hadiningrat who is far way from the discourse of eco-theology has naurallybuilt a paradigm related to the issue of environment based on his reflection on Islamic values and traditions. Forest which becomes his dominant environment where his pesantren is located has led him to cosmic awareness of the importance of conserving the mandat of God to human being. This awareness manifests in what is called "the words of forest" (kalam rimba) transferred to students and society around pesantren. In addition, Kiai Noer as the key actor also get involved in practical activities such as establishing vocational school of forestry to establish a continous transformation and implication for the conservation of forest with its ecosystem, particularly in Indonesia.
\end{abstract}

Keywords: The words of forest; ecotheology; pesantren.

\section{Pendahuluan}

Ekoteologi (Inggris: ecotheology) merupakan suatu istilah baru dalam ruang lingkup studi teologi yang berkembang dewasa ini. Ekoteologi diartikan sebagai epistemologi lingkungan berbasis pada teologi (Islam: kaläm) yang fokus mengkaji hubungan antara agama dan lingkungan. Secara partikular epistemologi ini dipahami sebagai episentrum keberpihakan agama terhadap alam semesta. Dimulai dari sebuah premis tentang hubungan antara religiositas dan spiritualitas manusia dengan fakta terjadinya degradasi serta krisis lingkungan 
hidup di bumi, disiplin ini berupaya mengeksplorasi interaksi antara nilai teologis dan kesadaran kosmis manusia yang berujung pada suatu refleksi dan aksi harmonis oleh manusia terhadap lingkungan sebagai bagian ekosistem di dalamnya. Wacana ini kemudian menjadi suatu gerakan yang menginspirasi banyak mega proyek pelestarian lingkungan hidup berbasis agama di berbagai belahan dunia.

Kesadaran manusia akan mendesaknya penanggulangan krisis lingkungan yang tengah terjadi di bumi, mendorong refleksi religiositas dan spiritualitas yang masif untuk merenungkan kembali tentang hubungan manusia dengan lingkungan yang kian menuju ke arah disharmoni. Refleksi ini kemudian memunculkan paradigma baru dalam pemahaman tradisi keagamaan terkait etika kosmologis yang dapat disebut dengan teologi atau kalam lingkungan, dimana agama dengan sistem nilai di dalamnya hadir untuk membimbing manusia mencapai kesadaran ekologis. Ada beberapa tokoh yang menjadi imam dalam gerakan dimaksud dari latar belakang agama yang berbeda. Di Islam ada Seyyed Hossein Nasr, ${ }^{1}$ di Kristen ada Jesuit Preist, di Katolik ada Matthew Fox, ${ }^{2}$ di Yahudi ada Abraham Joshua Heschel, ${ }^{3}$ dan di Hindu ada Vandana Shiva. ${ }^{4}$ Nasr yang disebut pertama mewakili sebagian pemikir Muslim yang menyerukan

${ }^{1}$ Professor Studi Islam di Universitas George Washington dikenal sebagai salah satu intelektual Muslim kontemporer terkemuka. Lahir di Teheran, 7 April 1933. Ide-ide pemikirannya menjadi sumber utama dalam studi tentang lingkungan dalam kerangka teosofi, Seyyed Hossein Nasr, Man and Nature: The Spiritual Crisis of Modern Man (London: George Allen dan Unwin, 1976); Seyyed Hossein Nasr, Religion and the Order of Nature (New York: Oxford University Press, 1996). Lebih lengkap tentang pemikiran Nasr bertema lingkungan dapat diakses di http: //www.nasrfoundation.org/audio/Environment.

2 Teolog Katolik Amerika yang lahir di Madison, Wisconsin tahun 1967. Ia pakar dalam bidang filsafat dan mistik Katolik yang dipelajari dari pendahulunya pada abad pertengahan seperti Thomas Aquinas, Dante, Meister Eckhart dan lainnya sehingga refleksi intelektualnya melahirkan gerakan yang disebut creation spirituality yang searah dengan konsentrasinya pada ekologi dan isu lingkungan pada akhir abad 20 dan berdampak pada popularitasnya di kalangan aktivis dan intelektual konservasi. Lihat https://en.wikipedia.org/wiki/Matthew_Fox_(priest). Diakses pada 13 Mei 2016, 10: 52.

3 Teolog Yahudi yang lahir di Warsaw, 11 Januari 1907. Ia pakar dalam bidang filsafat dan mistik Yahudi yang cukup terkenal pada abad 20 dan konser dalam isuisu lingkungan.

4 Aktivis lingkungan satu ini lahir di India, 5 November 1952 telah menulis sekurangnya 20 buku yang mengkokohkannya sebagai pemikir yang fokus terhadap isu-isu lingkungan internasional. Selain itu ia juga pimpinan dalam International Forum of Globalitation dan aggota komite ilmuan di Fundacion IDEAS. 
perlunya dilakukan tafsir ulang (reinterpretation) terhadap cara pandang agama dalam beberapa tema lingkungan dewasa ini. Bersama Özdemir, Nasr memobilisir masyarakat Muslim untuk turut serta mengatasi problem lingkungan, seperti perubahan iklim, penipisan lapisan ozon, penipisan sumber daya alam, penyempitan hutan tropis, kepunahan aneka ragam hayati, serta polusi udara dan air. ${ }^{5}$

Selama ini Nasr dan Özdemir memang cukup konsisten menyuarakan gerakan sadar lingkungan melalui karya tulis dan seminar dalam forum-forum internasional yang mereka ikuti. Nasr dikenal sebagai pemikir lingkungan (environment philosopher) semenjak menerbitkan hasil riset disertasinya yang disusun pada tahun 1958 dengan judul "An Introduction to Islamic Cosmological Doctrines" (1993) dan "Religion and the Order of Nature" (1996). Selain itu, Nasr juga dikukuhkan sebagai ilmuwan pemula di Barat yang konsisten menyuarakan isu-isu lingkungan. Menurut Nasr paradigma keilmuan modern telah mewariskan kekeliruhan cara pandang manusia ketika mendudukkan entitas di luar dirinya sebagai objek. Baginya, perkembangan sains telah mengobrak-abrik harmoni antara manusia dengan alam. Eksplorasi alam oleh sains modern memiliki kecenderungan ekploitatif yang menafikan kelestarian dan keberlangsungan alam itu sendiri. Alpanya upaya konservasi pascapemanfaatan alam demi kepentingan manusia memperburuk kualitas lingkungan hidup, sehingga oleh Nasr disebut sebagai "momok modernitas" yang perlu dikoreksi guna keberlangsungan hidup umat manusia.

Islam dan tradisi Timur yang muncul jauh sebelum modernisme telah memberi perhatian yang tinggi pada tema lingkungan. Bertolak dari nilai-nilai teologis yang diimani, Islam respek terhadap persoalan ekologi dengan membangun sistem etika lingkungan yang secara apik dinarasikan dalam al-Qur'ān untuk menjadi pedoman bagi pemeluknya. Tidak sedikit dapat ditemukan dalam sumber primer Islam tema-tema yang bercorakkan kosmologis. Beberapa surah misalnya menggunakan simbol-simbol kosmologis: tema fauna pada nama-nama surah seperti al-Baqarah (Sapi), al-An'ām (Binatang), alFīl (Gajah), al-'Ādiyāt (Kuda), al-Naml (Semut), al-Naḥl (Lebah), al'Ankabūt (Laba-laba); dan tema flora misalnya penggunaan kata, al-

\footnotetext{
${ }^{5}$ Nasr, Religion. Lihat juga, Özdemir, Ibrahim, 1998, "An Islamic Approach to the Environment". Diakses 10 Agustus 2014. http: //home.cogeco.ca/ drheault/ee_readings/Islam/ozdemir.pdf.
} 
fäkihah (buah), al-shajarah (pohon), al-ḥabbah (biji), al-tin (buah tin), serta secara naratif dapat ditemukan pada Q.S. al-Naḥl [16]: 10-11, Q.S. al-An‘ām [6]: 99, Q.S. Qāf [50]: 9-11. Hal ini menyiratkan bahwa Islam identik dengan isu lingkungan hidup. ${ }^{6}$

Sementara Indonesia dengan kekayaan ekologinya memiliki peran signifikan dalam isu lingkungan internasional (global-environment), sehingga julukan jantung dunia pun disematkan masyarakat global untuk bangsa ini. Posisi strategis dalam ruang lingkup lingkungan global serta mayoritas penduduk yang beragama, selalu menempatkan negara berjuluk zamrud khatulistiwa ini menjadi sorotan sekaligus barometer untuk pelestarian alam. Ada tesis menarik dari Monika Arnez yang disampaikannya dalam Shifting Notions of Nature and Environmentalism in Indonesian Islam, bahwa gerakan ramah lingkungan yang terjadi di Indonesia merupakan induksi dari nilai-nilai keyakinan ('aqidah) yang dimotori oleh organisasi Islam, utamanya masyarakat pesantren. ${ }^{7}$ Serupa dengan apa yang dipaparkan Arnez, Fachrudin Mangunjaya yang juga fokus pada studi lingkungan dan perubahan iklim dalam disertasinya menyebutkan komunitas pesantren bisa menjadi harapan untuk mengembangkan sekaligus menggerakkan aksi-aksi lingkungan di Indonesia melalui sistem keyakinan, tradisi keilmuan dan sosial yang telah terbentuk di dalamnya. ${ }^{8}$

Di salah satu pesantren Indonesia, yaitu Pesantren Walisongo yang terletak di Dusun Gomang Kecamatan Singgahan Kabupaten Tuban, wacana ekoteologi yang dikampanyekan oleh banyak tokoh dunia tidak sekadar menjadi ornamen intelektual. Namun, wacana ini sudah diimplementasikan pada ranah praksis oleh K.H. KPP. Noer Nasroh Hadiningrat (selanjutnya disebut Kiai Noer), pengasuh pesantren tersebut. Ide besar yang visioner untuk menyelamatkan alam mendorongnya pada satu titik reflektif untuk menanamkan nilainilai keyakinan kepada santri-santrinya dengan ajaran-ajaran kaläm (Islamic theology) yang pro pelestarian lingkungan hidup, yakni hutan. Tidak berhenti di sini, Kiai Noer juga mendirikan Sekolah Menengah Kejuruan Negeri (SMKN) Kehutanan untuk menyiapkan generasi Muslim masa depan yang sadar dan menjadi aktivis untuk mencegah

\footnotetext{
${ }^{6}$ Yusuf al-Qardhawi, Islam Agama Ramah Lingkungan, terj. Abdullah Hakim (Jakarta: Pustaka al-Kautsar, 2002), 77.

7 Schuler Barbara (ed.), Environmental and Climate Change in South and Southeast Asia (London: Brill, 2014), 75.

${ }^{8}$ Lebih jauh tentang riset Fachruddin bisa mengakses https: //unas.academia. edu/FachruddinMangunjaya.
} 
kerusakan alam dan melestarikan amanat Allah yang besar itu kepada khalifahnya, manusia.

Daya tarik lainnya adalah sosok Kiai Noer merupakan keturunan Ningrat dari kraton Surakarta dengan gelar Kanjeng Pangeran Panji (KPP) yang masih memagang tradisi dan nilai-nilai luhur ajaran Jawa yang identik dengan doktrin kosmologis. Sebagai seorang kiai yang telah mumpuni dalam penguasaan terhadap sumber-sumber primer Islam dan pelestari tradisi Jawa melahirkan struktur kesadaran yang padu. Perpaduan ini membangun kontruksi yang khas Nusantara, sehingga memunculkan suatu perspektif baru tentang "Kalam Rimba" (istilah penulis merujuk pada konsep ekoteologi yang khas). Tidak hanya itu, Nasr yang telah disebut kiprah dan keperduliannya terhadap lingkungan selama ini masih pada tataran ide dan konsep di wilayah akademik. Tetapi pengasuh pesantren Walisongo ini dapat merealisir potensi manusia sebagai khalifah fi al-ard pada bentuk praktis, yakni sebagai pelaku utama, narasumber sekaligus pengembang pelestarian hutan yang telah diamanatkan oleh Allah kepada manusia.

Selanjutnya, kertas kerja ini bertujuan untuk menarasikan secara detail renungan kalam rimba yang dikonsepsikan dan diaktualisasikan oleh Kiai Noer di Pensatren Walisongo dalam upayanya melestarikan rimba (baca: hutan) dengan berpedoman pada nilai-nilai teologis yang diimani dalam Islam dan berpadu dengan tradisi kosmologis Jawa khas Nusantara.

\section{Merajut Kalam Lingkungan}

Kritik atas kemapanan teologi lama yang meletakkan cara pandang antroposentris sebagai dasar ras manusia berperilaku smena-mena terhadap lingkungan, melahirkan konsep teologi baru yang mengkampanyekan pentingnya membangun kembali hubungan harmonis agama dan lingkungan. Salah satu kritik terlontar dari White dan lainnya menawarkan agar manusia beranjak dari monoteisme ke panteisme sebagaimana ditemukan pada tradisi agama Timur dengan cara membangun kesadaran kosmologis yang berwawasan spiritual dan sakralitas alam. ' Tawaran yang mirip juga datang dari G. Tyler Miller yang menyeru pengakhiran paradigma teologis yang kontraekologis seperti: dominasi, eksploitasi, destruksi dan penguasaan serta pengendalian penuh oleh manusia atas bumi dengan alasan bahwa

9 Lynn White Jr., "The Historical Roots of Our Ecological Crisis”, Science, Vol. 155 (1967), 24. 
manusialah yang menjadi bagian dari bumi, bukan sebaliknya. Cara yang ditawarkan Miller adalah dengan membangun relasi setara dan seimbang antara manusia dan alam. Tawaran ini digadang-gadang bisa menjadi solusi mengatasi krisis lingkungan yang kian mengkhawatirkan. $^{10}$

Ekoteologi adalah teologi transformatif yang dimunculkan untuk merelasikan agama dan alam (interrelationship of religion and nature). Kesadaran atas pentingnya pelestarian alam sebagai makrokosmos dimana umat manusia tinggal, menetap dan bergantung kepadanya menjadi dasar perspektif ekoteologi ini. Kemunculan diskursus ini disebabkan mendesaknya tafsir ulang terhadap teologi yang selama ini dipahami dengan keliru oleh umat beragama secara kolektif ketika menerjemahkan relasi antara manusia dengan alam semesta. Dalam paradigma ini, manusia cenderung diposisikan sebagai eksploitir, bukan pelestari alam setelah diamanatkan menjadi khalifah $f i$ al-'ard oleh Allah melalui firmannya dalam Q.S. al-Baqarah [2]: 30. Bahkan di ayat itu malaikat pun pernah memprediksi manusia akan gagal memegang mandat ke-khalifah-an itu.

Dari tafsir ulang ini, kedudukan manusia sebagai khalifah di alam semesta direduksi dan ditansformasi dari subjek eksploitir menuju subjek pelestari dengan menghadirkan "Yang Gaib" sebagai titik temu untuk mensinergikan relasi: tuhan, manusia dan alam. ${ }^{11}$ Nasr sebagai father of environmetal Islamic philosopher juga mengetengahkan hal yang sama bahwa kerusakan alam semesta tidak lain bersumber dari cara pandang manusia modern yang keliru. Seperti yang diungkapkan, the environmental crisis is primarily a result of an inner spiritual crisis of modern man and the darkening of the soul within man who then projects this darkness upon the environment and destroys its balance and barmony. (Krisis lingkungan adalah gambaran primer dari krisis spiritualitas manusia modern dan kegelapan jiwa manusia yang telah memproyeksi kegelapan bagi lingkungan dan memutus keseimbangan dan harmoni terhadapnya). ${ }^{12}$

Relasi segitiga antara Tuhan, manusia dan alam harus selaras, seimbang dan harmonis, demikian yang dapat dilakukan untuk tetap

${ }^{10}$ G. Tyler Miller, Reflenish The Earth: A Primer in Human Ecology (Belmnt Calif: Wadsworth, 1972), 53.

${ }^{11}$ Mujiono Abdillah, Fikih Lingkungan: Panduan Spiritual Hidup Berwawasan Lingkungan (Yogyakarta: Akademi Manajemen Perusahaan YKPN, 2005), 5.

12 Ibid. 
pada batasan harmoni seperti yang dituturkan Nasr. Sebab peniadaan satu sudut akan berdampak pada terganggunya hubungan keselarasan. Mungkin saja imbasnya adalah kemarahan Tuhan yang tampak dari reaksi alam berupa bencana. Inilah petaka yang sudah dinarasikan dalam ayat-ayat al-Qur'ān dengan varian kata yang mewakili. Terma bencana (Arab: musībab) dalam al-Qur'ān disebut sebanyak sepuluh kali: Q.S. al-Baqarah [2]: 156, Āl 'Imrān [3]: 165, al-Nisā [4]: 62, 72, Q.S. al-Mā'idah [5]: 106, al-Tawbah [9]: 50, al-Qașaṣ[28]: 47, al-Shūrā [42]: 30, al-Hadīd [57]: 22, al-Taghābun [64]: 11.

Menurut al-Raghīb al-Ashfihānī, asal makna kata musibah adalah al-ramyah, kemudian digunakan untuk pengertian bahaya, celaka, atau bencana dan bala. Al-Qurțubī mengatakan, musibah ialah apa saja yang menyakiti dan menimpa orang mukmin, atau sesuatu yang berbahaya dan menyusabkan manusia meskipun kecil. ${ }^{13}$ Bencana dalam al-Qur'ān memiliki makna yang beragam, tidak hanya mengandung makna kehilangan harta benda, tetapi juga terkait dengan masalah moralitas dan spirtualitas seseorang maupun masyarakat tertentu. Tandatandanya sudah nampak dalam kesadaran sebagian manusia ketika krisis global dan lingkungan hidup oleh sebab perilaku manusia terjadi dan menuju ke titik nadir.

Meskipun kritik dan beberapa tawaran dari tokoh-tokoh yang sudah disebutkan tidak sepenuhnya dapat diterima, atau bahkan ditolak dan dikritik balik oleh kelompok agamis, paling tidak argumentasi yang dibangun oleh White dan Miller bisa menjadi awal lahirnya visi restorasi pemikiran teologis yang selama ini masih menyisakan pemahaman keliru ketika memformulasikan relasi manusia dengan alam. Paling tidak kritik tersebut menyebabkan kemunculan gagasan teologis baru yang lebih arif terhadap alam berbekal doktrin agama, ekoteologi. Seiring waktu, gagasan teologi baru ini semakin dikenal dan disadari menjadi kebutuhan dan keharusan ketika sains an sich tidak dapat lagi memberi solusi yang komprehensif dalam menyelesaikan persoalan krisis lingkungan yang semakin parah.

Sejak awal, Islam telah mengajarkan etika ekologis sebagai piranti dasar bagi pribadi Muslim agar memperlakukan alam dengan baik. Doktrin etika ekologis inilah yang nantinya menjadi acuan dalam merumuskan visi dan misi kesadaran lingkungan (ecological conciousness),

13 Sahabuddin (ed.), Ensiklopedi al-Qur'ān: Kajian Kosakata, Vol. 2 (Jakarta: Lintera Hati, 2007), 657. 
di antaranya: tawhid (divine oneness), khalifah (vicegerency or stewardship) dan mizàn (balance). ${ }^{14}$ Dari landasan ini, hukum Islam (sharīah) menjadi perwujudan dari pendalaman terhadap formulasi ketuhanan yang disampaikan melalui al-Qur'ān dan Sunnah Nabi. Secara etimologis sharī'ah sendiri berarti "mata air". Artinya, sharī'ah menjadi sumber berperilaku yang di dalamnya memuat aturan-aturan dan prinsipprinsip etis. Arti ini identik dengan lingkungan, sebab mata air merupakan aspek penting dalam keberlangsungan ekosistem alam, flora dan fauna. Dapat dipastikan setiap makhluk hidup sangat bergantung kepada sumber air agar terus hidup, tidak terkecuali manusia.

Paradigma etik tentang lingkungan dapat ditemukan akarnya pada al-Qur'ān sebagai sumber primer Islam seperti berikut: Q.S. alBaqarah [2]: 60; Q.S. al-Qașaṣ [28]: 77; Q.S. al-Ahuāb [33]: 72; Q.S. alAn‘ām [6]: 165; Q.S. al-Fajr [89]: 17-18; Q.S. al-Naḥl [16]: 65; Q.S. Qāf [50]: 9; dan Q.S. al-An‘ām [6]: 38 dan 99. Dari ayat-ayat yang disebutkan, dapat disimpulkan bahwa konsep etika-ekologis telah jauh hari dikenalkan oleh al-Qur'ān sebagai pedoman utama bagi setiap Muslim ketika menjalani hidup di dunia. Kurang lebih intisari dari maksud (madlūl 'alayh) ayat-ayat yang disebutkan tadi adalah antikorupsi, manusia sebagai khalifah, pengentasan kemiskinan, pelestarian mineral, surga sebagi metafor alam yang indah, konservasi flora dan fauna, konsumsi makanan sehat, melindungi ozon, memahami ciptaan dan alam adalah manifes tuhan.

Tauhid yang menjadi dasar pijakan terbangunnya sistem keyakinan dalam Islam yang bertolak pada kepercayaan terhadap ke-Esa-an Allah sebagai pencipta semesta dan seluruh isinya, pengatur dan peliput dalam hukum alam yang telah ditetapkan adalah satu kesatuan yang mencakup tiga dasar dari shari'ah, iman dan ihsan. Pertama, sharíah berarti sistem nilai pokok yang mengakar dalam tradisi yang direfleksikan dari sumber-sumber primer yang diyakini yang lebih dikenal dengan rukun Islam (syahadat, salat, zakat, puasa dan haji). Kedua, iman berarti penegasan dari hati ke mulut kemudian menjadi sikap terhadap suatu wujud yang wajib (Allah, malaikat, kitab, rasul, kiamat, ketetapan dan takdir). Ketiga, ihsan berarti buah dari dua prinsip sebelumnya, dimana seorang Muslim mencapai titik kesadaran kulminasi dari ketauhidan, yang digambarkan ketika beribadah,

${ }^{14}$ FM. Khalid dan J. O’Brien (eds.), Islam and Ecology (London: Cassell Publisher Ltd., 1994). 
seorang hamba seolah memandang Allah, atau Allah selalu memandangnya.

Konsep tauhid di atas secara integral menjadi satu paradigma dalam kehidupan Muslim di dunia untuk menemukan dan membingkai ayat-ayat ciptaan (kawniyah) yang tersebar dalam semesta agar mencapai kesadaran tertinggi dari tauhid, yakni makrifat seperti yang telah dikonsepsikan oleh Ibn 'Arabī dengan Waḥdat al-Wujüd, Waḥdat al-Shubüd, serta Tajalliyăt. ${ }^{15}$ Sebagimana yang disampaikan dalam Q.S. al-An‘ām [6]: 39 dan Q.S. Ṭāhā [20]: 49, prinsip-prinsip tauhid yang diwariskan Islam yang sejalan dengan prinsip-prinsip lingkungan sebagai berikut:

1. Allah adalah pencipta dan pemilik tunggal atas alam semesta. Manusia hanya memiliki hak pakai atas apa yang disediakan oleh Allah.

2. Penyalahgunaan hak oleh manusia adalah hal yang dilarang dan berkonsekuensi hukuman.

3. Hak mengambil manfaat dari alam oleh manusia untuk kepentingan umum.

4. Pemanfaatan sumber daya alam yang terkontrol.

5. Kesejahteraan umum menjadi prioritas.

6. Maslahat (kebaikan publik) harus diutamakan.

Beberapa inti ajaran Islam di atas mengantarkan pada simpulan bahwa Nabi Muhammad dan sharíahnya sangat mendukung aksi konservasi, sehingga konsep teologi yang didakwahkan mengantarkan pada terciptanya harmoni manusia dengan alam. Sharíah juga mengenalkan konsep burum, berdasar pada waktu dan tempat. Ketika seorang Muslim melaksanakan haji, maka Muslim tersebut dilarang untuk membunuh binatang. Konsep ini juga berarti proteksi untuk kekayaan hayati. Oleh Tariq Ramadan apa yang dicapai oleh Nabi tentang kesadaran ekologi ini diistilahkan dengan upstream ecology dengan penjelasan bahwa konsep kesadaran ekologis ini tidak berhenti hanya pada tataran penanggulangan, tapi juga prevensi terhadap bencana. ${ }^{16}$

15 William C. Chittick, Dunia Imajinal Ibu 'Arabi: Kreativitas Imajinasi dan Persoalan Diversitas Agama, terj. Ahmad Syahid (Surabaya: Risalah Gusti, 2001).

16 Tariq Ramadan, The Messenger: The Meanings of the Life of Mubammad (London: Penguin Books, 2007), 202. 


\section{Kekhalifahan Manusia atas Alam}

Penegasan terhadap peran manusia selaku subjek dominan atas semesta dispesifikasikan sebagai doktrin alasan diciptakannya manusia. Status khalifah fi al-'ard yang diamanatkan oleh Allah kepada manusia bisa ditemukan dalam al-Qur'ān pada beberapa ayat: Q.S. alBaqarah [2]: 30, Q.S. Zukhruf [43]: 60, Q.S. al-An'ām [6]: 165, Q.S. alNaml [27]: 62, dan Q.S. Maryam [19]: 99. Jika ditelisik dari ayat-ayat al-Qur'ān yang ada kaitan dengan amanat agung yang diemban manusia sebagai "kaki tangan Tuhan" tadi, didapatkan pemahaman sebagaimana yang diungkap oleh Haleem, bahwa manusia punya kewajiban untuk menginvestigasi dan menyempurnakan "ciptaan" (alam raya dan semua isinya) dengan pengetahuan yang telah dibekalkan oleh Tuhan sendiri. Menurut pemikir Muslim ini, kesatuan, keseimbangan dan harmoni adalah fondasi pembangun semesta. Argumentasi ini berdasarkan deskripsi al-Qur'ān yang dapat dijumpai dalam beberapa ayat. Misalnya pada Q.S. Yasin [36]: 38-39 bahwa hukum keselarasan itu yang menjamin pergerakan tata surya sesuai orbit. Artinya tiap ciptaan dalam alam semesta ada semacam ketergantungan atau keterikatan antarsemuanya yang tak terputus, pun demikian dengan manusia dan alam raya berserta isinya.

Allah sebagai sumber awal, melalui ayat-ayatnya (kalam dan ciptaan) menegaskan akan wujud-Nya yang maha di atas segala yang telah diciptakan. Bagi kalangan materialisme sebagaimana diungkapkan dalam Dialectical Materialism oleh A. Sirin bahwa kesatuan dan ketergantungan yang paling intim antara manusia dan alam secara nyata terletak pada biospher, selimut tipis bumi yang menghimpun hubungan materialistik antarentitas. Jika salah satu materi menghilang akan mempengaruhi materi yang lain. Maka jika alam tidak ada, tentu manusia pun sirna. ${ }^{17}$ Sedangkan manusia adalah makhluk yang paling siap sebagaimana yang ditetapkan oleh penciptanya sendiri untuk menerima amanah menjaga keselarasan antara: Tuhan, semesta dan dirinya. Agar harmoni ini tercipta, Tuhan membebankan kewajiban bagi manusia untuk beribadah, taat pada hukum-hukum yang ditetapkan, respek terhadap lingkungan dan menjauh dari dosa dan

\footnotetext{
17 https: //www.marxists.org/reference/archive /spirkin/works/dialecticalmaterialism/ch05-s03.html. Diakses 20/05/2015 13: 25.
} 
larangan tuhan. ${ }^{18}$

Dalam diskursus ekoteologi, menafsir ulang peran ke-khalifah-an manusia adalah titik tolak terwujudnya "aksi-aksi hijau (green activism)". Keyakinan ini senada dengan yang disuarakan oleh banyak pemikir Muslim. Haleem mengatakan, bahwa titik tekan dalam memberi gambaran tentang bahasan dalam tema ini adalah wahyu Allah Q.S. [al-Baqarah[2]: 30: I am putting a successer on earth, ${ }^{19}$ dan Q.S. al-A'rāf [6]: 165: It is be who made you successors on the earth and raises some of you above others by rank, to test you through what He gives you. ${ }^{20}$ Ayat-ayat tersebut tidak hanya memberi pesan bahwa Allah telah menciptakan alam semesta semata untuk kepentingan manusia, tetapi juga ada kewajiban bagi orang yang beriman untuk menjaga, bersikap ramah terhadap lingkungan dan melestarikannya. Beberapa sumber hadīth juga menyebutkan kewajiban manusia sebagai khalifah menuntut manusia tidak berlebihan dalam memanfaatkan kekayaan alam. Contoh kecilnya dapat ditemukan dalam perintah efesiensi penggunaan air ketika berwudlu.

Sebagaimana disimpulkan oleh Assisi Declarations (1986), Gardner, Gerald dan Stern (2002) bahwa ke-khalifah-an adalah konsep sentral etika lingkungan dalam ajaran agama Abrahamik dan basis dari ekoteologi yang telah dikembangkan dalam forum dialog antaragama untuk penyelamatan alam raya. Rekontruksi pemahaman terhadap makna "kaki-tangan Tuhan" yang semula anthropocentric dominant sebagaimana ajaran klasik agama dan diamini oleh modernisme, menggugah ide transformatif untuk merumuskan formulasi pemahaman teologi tentang "amanah Tuhan" bagi manusia terhadap alam yang akan punya konsekuensi pertanggung-jawaban di peradilan Tuhan pasca kematian manusia (akhirah atau the hereafter).

\section{Pesantren Walisongo dan Kiai Noer Nasroh}

Berdiri di sebuah areal perbukitan dengan ketinggian 470 meter di atas permukaan laut yang dikelilingi hutan jati membuat Pondok Pesantren Walisongo Gomang, Desa Lajolor, Kecamatan Singgahan, Kabupaten Tuban, terasa teduh dan sejuk. Jika menempuh rute

18 Monika Arnez, "Shifting Notions of Nature and Environmentalism in Indonesian Islam" dalam Barbara Schuler (ed.), Environmental and Climate Change in South and Southeast Asia How are Local Cultures Coping? (Leiden: Brill, 2014), 80.

19 M.A.S. Abdel Haleem, The Qur'ān, 7 (Surah [2]: 30) (New York: Oxford University Press, 2004).

${ }^{20}$ Ibid. 
perjalanan Bojonegoro-Jatirogo-Tuban, pesantren ini terletak 37 kilometer dari Kabupaten Bojonegoro dan 45 kilometer dari Kota Tuban.

Kekhasan kurikulum pesantren Walisongo adalah terletak pada perpaduan (integrity) antara pendidikan agama (religion based education) dan pendidikan lingkungan (environtment based education). Di pesantren ini, santri tidak hanya dibekali doktrin agama sebagai dasar keperdulian terhadap alam dan lingkungan. Namun juga dipadukan dengan pengetahuan saintifik dan keterampilan yang berhubungan dengan lingkungan tempat tinggalnya. Di sini para santri dibiasakan turut serta dalam aksi penghijauan, reboisasi, pemeliharaan dan pengayaan tanaman hingga penerapan konservasi tanah pada lahan kritis dan tidak produktif serta penyelamatan sumber mata air di lingkungan sekitar pesantren yang notabene adalah hutan.

Aksi nyata yang telah dilakukan pesantren ini untuk menegaskan identitas sebagai eco-pesantren di antaranya adalah kegiatan penghijauan yang dilakukan di petak 11 bagian Kesatuan Pemangkuan Hutan Mulyoagung dan Kesatuan Pemangku Hutan Parengan seluas 78,3 hektar, juga di petak 26 yang seluas 23 hektar. Penyelamatan mata air di Pacing seluas 5 hektar, Prataan 8 hektar, dan Malo 5 hektar. Selain itu, penghijauan juga dilakukan di hutan rakyat di Podang seluas 38 hektar, Ngaglik 65 hektar, Banyubang 4 hektar, Mbaro 8 hektar, Kumpulrejo 1 hektar, dan Gomang 5 hektar. Serta rehabilitasi penyelamatan sumber mata air dilakukan di beberapa titik.

Paradigma pro lingkungan yang nampak dari citra kurikulum dan program pesantren merupakan hasil refleksi pengasuh, Kiai Noer karena keprihatinannya terhadap kondisi lingkungan di sekitar pesantren seperti yang dituturkannya, Dulu saat butan rusak, dari 17 mata air hanya tinggal delapan yang berair. Setelah ada upaya rehabilitasi, kini 14 mata air telah menyemburkan air. Tinggal tiga yang mulai keluar sedikit demi sedikit. Sedangkan sumber mata air di Krawak saja bermanfaat untuk kebutuban air bersib bagi 10 Desa di Kecamatan Montong dan delapan desa di Kecamatan Singgahan. Sumber mata air yang mengalir melalui Bendung Nglirip bisa mengairi 3.800 bektar sawah. ${ }^{21}$

Selain gerakan konservasi, Kiai Noer juga menginisiasi aksi pemberdayaan masyarakat sekitar pesantren sebagai pengalih agar masyarakat setempat tidak bersikap eksploitatif terhadap lingkungan

${ }^{21}$ http: //pp-walisongo.blogspot.com/p/tentang.html. Diakses pada 20 Juli 2016. 14: 33 . 
melakukan pembalakan hutan-yang sebelumnya bisa disebut sebagai profesi. Output yang paling penting dari Kiai Noer adalah berdirinya Sekolah Menengah Kejuruan Negeri (SMKN) I Kehutanan bekerja sama dengan Perusahaan Hutan Negara wilayah setempat yang berdiri sejak tahun 2006 silam.

\section{Dari Ilmu Jaduk ke Penjaga Rimba}

Sejak berdiri sampai saat ini banyak perkembangan yang terjadi di pesantren Walisongo. Pesantren yang awalnya fokus pada model pendidikan salaf, kini menjelma menjadi pesantren yang berhasil memadukan antara tradisi dan kemajuan zaman. Pendapat ini bukan tanpa bukti, berdasarkan pengalaman penulis pada tahun 1998 dan 1999, ketika bangsa ini diterpa isu teror yang dikenal dengan "Ninja", pesantren ini banyak menjadi rujukan bagi masyarakat di wilayah Jawa Timur. Kepanikan sebab teror tersebut membawa masyarakat berkeinginan mendapat ilmu kekebalan secara instan untuk membentengi diri atau menjadi relawan keamanan (pamswakarsa) di tempat tinggalnya. Apapun tendensi dan motif personal yang muncul dari sekian ribu orang yang datang ke pesantren Kiai Noer yang kadung tersohor sebagai pendekar "jaduk" (kebal dari senjata tajam), penulis menangkap pesan teologis pada kasus ini, sehingga perlu diuraikan dalam tulisan ini.

Proses mendapatkan "ilmu kebal" sangat sederhana. Setelah menelan beberapa pelor yang direndam minyak wangi (jenis: misik) dengan bantuan buah pisang, setiap orang kemudian dipersilahkan masuk ke bilik yang minim pencahayaan, sebab pada saat itu memang pasokan listrik masih terbatas untuk wilayah pesantren ini berada, hanya mengandalkan tenaga diesel. Kiai Noer lalu me-rajab (menulis simbol-simbol tertentu) di atas kulit punggung dengan menggunakan pucuk sebilah keris sambil duduk bersila. Setelah selesai, orang tersebut diminta tengkurap, dan sekelebat mata kilau dari pedang yang tajam berayun beberapa kali menyentuh permukaan kulit. Tapi tidak ada darah menetes hanya seperti pukulan benda tumpul yang sangat keras. Itu tanda orang tersebut sudah menjadi kebal terhadap senjata tajam.

Setelah proses pertama, para pencari kekebalan lalu diarahkan ke sebuah sumber mata air pada tengah malam di dalam hutan untuk melakukan ritual rendaman (Jawa: kungkum). Di sebuah area sumber mata air, semua orang mulai menceburkan diri ke dalam telaga, lalu 
beberapa kali meneggelamkan kepala mereka sambil baca wirid dari ayat al-Qur'ān yang telah diijazahkan oleh Kiai Noer: la tudrikubu alabșär wa buwa yudriku al-abșär wa buwa al-latif al-khabir (Q.S. al-An‘ām [6]: 103). Sehabis rendaman, ritual berikutnya adalah berzikir melafalkan kalimat tauhid là iläh illà Allăh dengan menahan nafas sekuatnya dan memusatkannya pada bagian antar perut dan dada, serta berkosentrasi merasakan energi yang menjalar di dalam tubuh. Pada akhir tahapan ritual itu, Kiai Noer berwasiat agar menjauhi lima perbuatan jahat yang dikenal dengan "mo limo": (1) main, (2) madon, (3) mendem, (4) madat, dan (5) maling.

Narasi cerita di atas merupakan awalan untuk sampai pada sebuah simpulan yang dapat ditarik sinerginya dari rangkaian proses ritual, bahwa keselarasan dan harmoni antara manusia, alam dan Tuhan terwakili dalam bentuk-bentuk simbol dari tahapan yang telah diuraikan. Selain pengalaman dari pengamatan penulis, agar refleksi teologis yang telah dilakukan aktor primer, Kiai Noer dalam merumuskan konsep ekoteologi dan menjadi pendekar rimba ketika memutuskan mencetak santri-santri pelestari ligkungan di pesantrennya, penulis memaparkan beberapa poin yang menggambarkan renungan ekoteologis Kiai Noer tersebut sebagai berikut:

\section{Pemahaman Aktor dalam Pelestarian Lingkungan}

Dalam pendalaman yang dilakukan penulis, Kiai Noer sebagai tokoh sentral mempunyai pemahaman yang mendalam tentang dasar hukum kehutanan yang berlaku di Indonesia, sehingga ia dapat menguraikan substansi peraturan itu dengan amat jelas:

Defenisi hutan adalah kumpulan ekosistem yang berada di hamparan luas, terdiri dari tumbuhan, air, batu, tanah dan sebagainya. Berdasarkan Undang-undang RI Nomor 41 Tahun 1999 dijelaskan pada pasal 18 ayat 2, bahwa luas kawasan hutan yang harus dipertahankan sebagaimana dimaksud ayat (1) minimal $30 \%$ (tiga puluh persen) dari luas daerah aliran sungai dan atau pulau dengan sebaran yang proposional. ${ }^{22}$

2. Manfaat Hutan dan Nilai Teologis sebagai Asas Aksi Pelestarian Hutan

Undang-undang RI Nomor 41 Tahun 1999 tentang kehutanan dan kondisi hutan sekitar yang kritis menjadi alasan kognitif Kiai Noer yang mengantarkannya pada suatu refleksi teologis akan

${ }^{22}$ KH. Noer Nasroh, Wawancara, Tuban 17 Juli 2016. 
mendesaknya penyelamatan hutan. Fakta bahwa indikasi kerusakan hutan di Tuban semakin parah menjadi salah satu faktor pendorong bagi perumusan satu strategi penyelamatan yang berkelanjutan (sustainable) dan berdampak makro. Upaya reflektif ini yang membawa pada satu kesadaran atas manfaat hutan untuk keberlangsungan hidup manusia, di antara manfaat itu terdapat dalam penuturannya:

Sebagaimana yang dituntut oleh undang-undang kehutanan dan didasari kesadaran atas manfaat hutan yang banyak, di antaranya: (1) Hutan sebagai pencegah hama pertanian dan perkebunan. Analoginya adalah jika kondisi hutan rimbun dan lebat, maka hewan-hewan yang dikenal sebagai penyebab kerusakan tanaman tidak akan meninggalkan ekositem aslinya karena ketersediaan makanan yang melimpah. Kutu loncat yang juga menjadi hama tanaman pertanian dan perkebunan akan terhambat migrasinya oleh angin karena keberadaan pohon-pohon yang berdaun lebat dan rimbun. (2) Hutan sebagai sumber kehidupan. Dengan keberadaan hutan yang sehat, oksigen sebagai udara yang dibutuhkan manusia diproduksi oleh pepohonan yang ada di dalamnya. Sedangkan karbon dioksida yang tidak dibutuhkan oleh manusia ditampung olehnya. Hutan juga salah satu aspek pembentuk biospher yang dibutuhkan untuk keberlangsungan kehidupan di muka bumi. (3) Hutan sebagai benteng pertahanan terhadap bencana. Suatu misal angin yang datang dari laut lepas yang tidak ada penghambatnya sama sekali akan berbahaya jika tidak ada hutan sebagai pengola. Karena keberadaan hutan dan ekosistem di dalamnya, angin kencang yang datang dari lautan dihambat oleh ciptaan Allah berupa perbukitan dan diproses menjadi udara yang sehat dan menyegarkan. Tidak menjadi bencana yang merusak apa yang telah dibangun oleh manusia. (4) Hutan sebagai sekuritas aset ekonomi. Secara tidak langsung keberadaan hutan dan ekosistem di dalamnya telah menyelamatkan aset ekonomi yang dimiliki manusia. Sebagai peredam petir kala musim hujan, hutan menyelamatkan sekian juta milliar rupiah. Sebab jika pohon-pohon yang ada di hutan tidak menangkap aliran listrik yang besar dari petir karena pertemuan arus positif dan negatif yang terjadi di langit lalu dialirkan ke bumi, maka bisa dapat dipastikan alat elektronik, rumah dan aset yang dimiliki manusia akan hancur oleh arus listrik yang besar tersebut jika saja tidak diredakan oleh hutan. Dengan demikian tidak dapat dibayangkan berapa besaran kerugian yang akan ditanggung oleh manusia dari 
sisi ekonomi jika benar-benar terjadi saat ini, ketika ketergantungan umat manusia tidak terelakkan lagi dari perangkat elektronik. ${ }^{23}$

Dari refleksi terhadap manfaat atas keberadaan hutan dapat disimpulkan bahwa Allah telah menciptakan alam semesta ini begitu detail, sehingga akal manusia tidak akan dapat menjangkau keseluruhan dari rahasia-Nya. Ini akan melahirkan tauhid ulühiyah dan rubübiyah pada diri manusia. Selain itu, upaya melindungi dan melestarikan hutan dalam perspektif teologis juga manifestasi dari tugas manusia: sebagai hamba ('abd) pada ranah esoteris; dan amal jariyah pada ranah eksoteris. Mengingat manfaat hutan yang telah disebutkan tadi berdampak pada kebaikan terhadap manusia lain, tentunya akan bernilai pahala di hadapan pencipta. Apa yang dihayati Kiai Noer akan manfaat hutan dalam penjelasan Özdimer bisa dikategorikan sebagai upaya menangkap pesan Tuhan dari ciptaanNya. ${ }^{24}$

\section{Dari Teologis ke Teopraksis Demi Penyelamatan Hutan}

Kesadaran teologis atas manfaat keberadaan hutan dan krisis yang mulai nampak dari keberlangsungan ekosistem hutan, maka didirikanlah di pesantren Walisongo sekolah kejuruan yang bertema dan berorientasi kehutanan, yakni Sekolah Menengah Kejuruan Negeri (SMKN) Kehutanan. Ini menegaskan bahwa ada kemajuan dari teologi ke teopraksi yang dialami oleh Kiai Noer untuk mewujudkan visi dan misinya sebagai pendekar rimba, secara runut Kiai Noer menuturkan pada peneliti hasil renungannya sehingga aksi itu menjadi nyata:

Dasar teologis yang dapat dijadikan referensi dari sumber primer Islam dalam hal tuntutan atau kewajiban dan tanggung jawab manusia terhadap kelestarian hutan, dapat dilihat dari bagaimana al-Qur'ān membahasakan hutan dengan kata jannah yang berarti "kebun" dalam bahasa Indonesia, sebagaimana termaktub pada ayat wa jannātin al-fäfā (Q.S. al-Naba' [78]). Artinya, kebun yang rimbun dan gelap seperti malam.

Selain itu hutan juga bisa mencegah banjir dan tanah longsor, karena setiap pohon dengan jarak keliling $40 \mathrm{~cm}$ sudah dapat menampung air sejumlah 40 liter. Jadi kalau 1 hektare lahan dengan pohon ukuran 3 x 4 diameter 10 maka terhitung ada 800 pohon yang ditanam dan bisa menampung 1600 liter air di tanah. Seiring

\footnotetext{
${ }^{23}$ Ibid.

24 Özdemir, Ibrahim. 1998. "An Islamic Approach to the Environment." http: //home.cogeco.ca/ drheault/ee_readings/Islam/ozdemir.pdf.
} 
waktu kebutuhan pohon terhadap air akan semakin besar yang menyebabkan terbukanya permukaan tanah jika stok air semakin menipis. Tanah yang terbuka tersebut ketika musim hujan datang akan dengan cepat menyerap air hujan sehingga mencegah aliran air yang besar atau banjir juga tanah longsor.

Sedangkan di Indonesia ini, pengelolaan hutan menjadi tanggung jawab instansi yang dibentuk oleh pemerintah melalui Perhutani, terdiri dari Kesatuan Pemangkuan Hutan $(\mathrm{KPH})$ yang bertanggung jawab untuk rata-rata 45.000 hektare hutan di wilayah kerjanya. Di Divisi Regional Jawa Timur terdiri dari: $23 \mathrm{KPH} ; 3 \mathrm{KBM}$ Pemasaran; 1 KBM Industri Kayu; 1 KBM Industri Non Kayu; 1 KBM Agroforestry dan 1 KBM Jasa Lingkungan dan Produksi lainnya serta $5 \mathrm{SPH}$; seluas 1.134.052,0 Ha. Di bawah KPH ada KBKPH yang dipimpin seorang Asisten Perhutani (Asper/Sinder) yang membawahi $5 \mathrm{KRPH}$ yang dipimpin seorang Mantri. Jadi setiap KRPH rata-rata bertanggung jawab terhadap 9000 hektare hutan dengan jumlah personil termasuk Mentri sebanyak 10 orang. Tentu ini sangat terbatas jika dibanding dengan luas area hutan yang menjadi tanggung jawabnya.

Hal ini yang kemudian mendorang pesantren untuk berpikir bahwa selama ini pemerintah sangat kekurangan tenaga dalam pengelolaan hutan di Indonesia. Refleksi ini mengantarkan pada pertanyaan apakah kerusakan hutan hanya disebabkan oleh kurangnya kesadaran masyarakat atau kurangnya kapabelitas pengelola? Tetapi hipotesis yang muncul lebih cenderung mengatakan tidak maksimalnya manajerial menyebabkan persoalan kerusakan hutan terjadi, baik oleh masyarakat atau alam itu sendiri. Dalam suatu hạdìth disebutkan bahwa idhā wussida al-amr ilā ghayr ablih fantaz̧ir alsäah (Bukhārīi 6131). Kehancuran dimaksud adalah lebih dipandang dari sisi dalam dari pada luar, karena menyangkut tugas mengatur atau memimpin, meskipun sisi luar yakni penanaman kesadaran masyarakat akan kelestarian hutan juga perlu dipandang untuk langkah perbaikan selanjutnya.

Alasan inilah yang mendorong kami di pesantren mendirikan sekolah kejuruan berorientasi kehutanan. Selain manfaat hutan yang banyak, kami menyadari bahwa keberlangsungan pelestarian hutan juga membutuhkan banyak tenaga kerja terampil yang dilibatkan. Belajar dari apa yang telah dilakukan Belanda ketika itu, mereka menanam sepanjang jalan yang mereka bikin dengan pohon asem dan mahoni, karena salah satunya adalah daun dari pohon asem dan mahoni memiliki daun-daun yang kecil dan lembut, sehingga dapat meredam polusi suara dan udara dari 
kendaraan yang melewati. Lho masak Belanda bisa kita kaum santri tidak bisa!. ${ }^{25}$

4. Penafsiran Peran Manusia sebagai Khalifat Allab di Bumi

Dalam menangkap pesan yang disampaikan oleh al-Qur'ān tentang tugas manusia dan relasinya dengan alam semesta, Kiai Noer mempunyai penjelasan menarik. Sebagaimana yang diungkapkan oleh Haleem, bahwa manusia punya kewajiban untuk menginvestigasi dan menyempurnakan ciptaan dengan pengetahuan yang telah dibekalkan oleh Tuhan. Manusia telah menerima kontrak sebagai hamba dan wakil tuhan di bumi, tentu memiliki konsekuensi teologis bahwa amanah itu akan dipertanggungjawabkan di akhirat. Penjelasan tentang tanggung jawab manusia terhadap amanah khalifah oleh Kiai Noer dijelaskan sebagai berikut:

Firman Allah, qäla innì jäìl fì al-ard khalifah (Q.S. al-Baqarah [2]: 30) dalam pandangan kami memiliki pemaknaan yang ditekankan pada peran ke-khalifah-an. Manusia sebagai individu memiliki tanggung jawab yang sama sebagai hamba ('abd) dan pemimpin (khalifah), baik dalam lingkup sosial terkecil maupun besar. Keluarga membutuhkan pemimpin, lebih kecil lagi dalam ibadah salat, meskipun hanya dua orang misalnya harus ada yang berperan sebagai imam dan makmum biar bisa berjamaah. Demikian juga dalam lingkup besarnya adalah bermasyarakat dan bernegara.

Jika merujuk pada ilmu tata negara, terdapat tiga macam model kepemimpinan, yaitu: otoriter, demokrasi dan laissez faire. Semestinya, antara peran hamba dalam fungsi marginal dan pemimpin dalam fungsi dominan dapat dihayati secara seimbang, sehingga nantinya akan memunculkan sinergi dalam diri seseorang untuk menjalani peran sebagai pelayan Allah dan pelindung makhluk, termasuk alam dan isinya. Oleh karena itu kami tekankan bagi keluarga dan santri di sini untuk menghayati makna dari ayat Allah, qū anfusakum wa ablikum nāran, allatì waqüduha al-nār wa albijärah 'uiddat li al-keäfirin (Q.S. al-Tahrīm: 6). Lingkup kecil peran manusia adalah memberi perlindungan bagi dirinya dan keluarganya dari api neraka. Berarti dalam hal ini terdapat perpaduan antara posisi sebagai 'abd dan khalifah.

Untuk memenuhi kewajiban dan amanah itu, seorang manusia harus bertindak berdasarkan aturan-aturan Allah. Ya beribadah, tidak maksiat, tidak melanggar larangan dan menjalankan perintah yang ditetapkan Allah juga rasul-Nya. Termasuk menghargai ciptaannya, alam semesta ini, seperti hutan dan ekosistem di

${ }^{25}$ KH. Noer Nasroh, Wawancara, Tuban 17 Juli 2016. 
dalamnya. Kami di pesantren lebih cenderung memilih model kepemimpinan yang terpadu antara model kepemimpinan yang sudah dikenalkan Nabi Muhammad melalui hạadith-ḥadīthnya dengan model kemimpinan dari teori-teori modern. Untuk mempertegas peran ini maka di sini juga dikenalkan ilmu bela diri (kanuragan) sebagai implementasi dari upaya melindungi diri dan keluarga serta lingkungan termasuk hutan. Itulah filosofi dari ilmu kanuragan. ${ }^{26}$

5. Sekolah Kejuruan Berorientasi Kehutanan Wujud Nyata Ekoteologi Visi untuk mencetak generasi Muslim yang respek dan memiliki tanggung jawab yang besar terhadap kelestarian alam sebagai upaya induktif atas sumber al-Qur'ān dan sunah membuktikan keseriusan Kiai Noer untuk membangun satu paradigma yang mengakar pada nilai-nilai Islam. Kesadaran (conciousness) untuk selalu perduli terhadap keselarasan alam secara kuat tertanam sebagaimana keyakinan tauhid kepada Allah dan menerima Islam sebagai agama yang dianut dan diyakini. Menyeimbangkan antara prihal dunia dan akhirat dalam misi lingkungan yang digagas oleh Kiai Noer dapat dipahami dari paparannya berikut:

Refleksi ini yang telah kami sampaikan tadi menjadi pertimbangan untuk mendirikan sekolah kejuruhan yang menyediakan kader perduli, sekaligus siap kerja dalam bidang kehutanan, mengingat fakta akan kebutuhan tenaga terampil dalam bidang ini, dalam hal ini pengisi pos-pos kerja di Perhutani juga profesi-profesi lain dari berbagai instansi yang membutuhkan tenaga terampil yang kompeten dalam bidang kehutanan, baik di pemerintahan dan swasta. Selain itu, semoga misi ini juga menjadi amal jariyah bagi kami karena memberi kemanfaatan bagi umat manusia dan alam.

Dalam suatu hadīth pernah diriwayatkan, suatu kali Nabi Muhammad melewati area kuburan, lalu nabi mengambil pelepah kurma dan meletakkannya di atas kuburan yang ketika itu beliau mendengar suara tangisan dari dalam kuburan itu. Setelah pelepah kurma tersebut ditaruh, tangisan itu menjadi reda dan tak terdengar lagi. Sahabat yang penasaran bertanya, kenapa nabi melakukan hal demikian? Nabi menjawab bahwa orang yang berada di kuburan itu sedang disiksa oleh Allah karena tidak memperhatikan kesucian ketika kencing. Maka pelepah itu dapat meredakan siksa dari orang itu. Hal demikian dilakukan oleh Nabi pada kuburan yang lain dan memberi keterangan bahwa si penghuni kubur ini suka adu domba.

\footnotetext{
${ }^{26}$ Ibid. Pandangan ini juga diiyakan oleh RM. Abraham Naja Mangku Negara dalam wawancara yang dilakukan peneliti.
} 
Dus, pelepah kurma yang dapat meredakan siksa sebagaimana yang disunahkan Nabi mengisyaratkan bagi umatnya untuk melindungi pepohonan. Ini yang sedang kami teladani di pesantren. ${ }^{27}$

6. Pelestarian Hutan Berbasis Teologi, Menolak Tesis Agama NirEkologi.

Tesis Lyenn White yang didasari keputusasaan terhadap agama dalam upaya melawan kerusakan alam, membuatnya berkesimpulan bahwa penyebab kerusakan lingkungan adalah aksi dominasi manusia terhadap alam. Sebab upaya penguasaan manusia terhadap semua entitas dihadapannya mengantarkan ke titik nadir krisis lingkungan yang menghimpit manusia sendiri, berupa bencana lingkungan seperti polusi, banjir, lonsor dan sebagainya. Sekilas, simpulan White agar manusia kembali kepada konsep keberagamaan Timur dan panteisme ada benarnya. Sebab di Indonesia sendiri sebelum kedatangan agama Abrahamik, kepercayaan Animisme dan Dinamisme seolah menjadi benteng untuk menjaga alam dan lingkungan dari kerusakan. Sakralitas hutan dan ekosistem di dalamnya disimpulkan menjadi suatu iman dan ketaatan. Tetapi tesis bahwa agama monotiesme antiekologi pun lemah jika White dapat menangkap pesan agama seperti dituturkan Kiai Noer berikut ini:

Jika dikatakan bahwa agama Islam sebagai pemicu kerusakan alam sebab potensi dominasi atas alam, sebagaimana yang dikabarkan dalam al-Qur'ān, ini tidaklah benar. Fakta historis yang dapat membantah simpulan oleh sebagian pihak yang mendeskreditkan agama dalam persoalan ekologi adalah kenyataan bahwa dalam sejarah Islam di Nusantara, orang-orang mulia seperti wali songo justru kita temukan makam-makam mereka berada di puncak dataran tinggi dan hutan. Pun dengan raja-raja di Jawa yang diceritakan ketika melakukan semedi, mereka pergi ke hutan. Oleh karenanya, dapat disimpulkan berarti hutan merupakan tempat yang dapat menjadi media untuk mendapatkan daya spiritual karena sifatnya yang sunyi dan penuh dengan hawa positif.

Kalau dalam diskursus sufistik bahwa syarat mendapatkan derajat wali di antaranya 'uzlah (menyepi), maka hutan menjadi pilihan seperti yang telah dilakukan oleh orang-orang mulia sebagaimana yang kita kenal, misalnya Sunan Giri, Sunan Muria dan raja-raja di Nusantara. Menurut pemahaman kami, di tempat yang sunyi seperti hutan, Allah menyimpan dan menyembunyikan harta karun-Nya, yakni hamba-hambanya yang saleh. Demikian ini dapat dianalogikan seperti material tambang. Jika kita menggali 60 meter

${ }^{27}$ KH. Noer Nasroh, Wawancara, Tuban 17 Juli 2016. 
ke dalam dari permukaan bumi, kita akan hanya mendapatkan tanah dan bebatuan, 60 meter berikutnya akan mendapatkan batubara, dan 60 meter selanjutnya baru akan kita temukan emas. Secara tidak langsung, semakin rahasia dan tersembunyi sesuatu itu maka nilainya semakin mahal dan mulia. Sama juga dengan manusia, semakin ia tersembunyi, maka semakin mulia pula dirinya. Selain itu, hutan faktanya juga identik dengan agama. Suatu misal, dalam Islam dikenal istilah tahärah (bersuci) sebagai syarat ibadah, sedangkan media yang paling utama adalah air. Jika hutan sebagai tempat penyimpanan air rusak, tentu kita sebagai umat Muslim tidak bisa melakukan keutamaan bersuci dengan air dari sumber mata air yang diproduksi oleh hutan. Maka hutan harus diselamatkan, karena hutan yang menyebabkan adanya mata air itu. Selanjutnya, dapat disimpulkan bahwa air identik dengan ibadah dan kehidupan sebagaimana yang dijelaskan dalam al-Qur'ān. Akhirnya, jika kita menyelamatkan hutan, maka berarti kita ingin ibadah dan hidup di muka bumi ini sekaligus taat kepada Allah. ${ }^{28}$

7. Siginifikansi dan Keberlanjutan Upaya Pelestarian Hutan di Pesantren Walisongo

Apa yang telah dikembangkan oleh Kiai Noer selaku aktor primer di pesantren Walisongo Gomang tidak hanya sebatas konsep tanpa memiliki dampak signifikan terhadap perubahan cara pandang masyarakat dan keberlanjutan di masa mendatang sebagai upaya pelestarian hutan dan pemberdayaan masyarakat di Tuban. Dari keterangan yang disampaikan setidaknya keberadaan sekolah kejuruan itu memiliki dampak besar menyelesaikan krisis lingkungan di daerah setempat, sekaligus meningkatkan kesejateraan masyarakat seperti yang tersurat dalam penjelasan aktor:

Memang segala sesuatu yang muncul di tengah masyarakat akan mengundang pro dan kontra. Pun demikian dengan pendirian sekolah kejuruan di pesantren ini. Jika dihitung, kuantitas yang tidak sepakat sangat kecil dibanding yang mendukung keberadaan sekolah. Sebab sebelum pesantren ini didirikan, mayoritas masyarakat di sini menggantungkan ekonomi mereka pada jobong, tempat untuk meproduksi gamping sebagai sumber perekonomian utama. Setidaknya ada 40 jobong di sekitar pesantren. Sedangkan kebutuhan seluruh jobong ketika produksi, kami perkiraan antara 1400 sampai 1500 kubik kayu untuk bahan pembakaran batu kapur dari proses awal hingga menjadi gamping. Tentu ini berdampak pada semakin parahnya kerusakan hutan di wilayah ini. Kebutuhan

${ }^{28}$ Ibid. 
ekonomis akan kayu hutan mendorong terjadinya pembalakan liar oleh oknum masyarakat.

Kemudian, kami diajak oleh pemerintah dan Perhutani untuk bersama-sama menanggulangi krisis hutan itu. Sebenarnya, kami juga dihadapkan pada sebuah dilema. Jika pembalakan liar ditindak tegas, maka berdampak pada menurunnya taraf ekonomi masyarakat. Tapi jika tidak segera ditindak, maka bisa jadi dampaknya akan semakin besar karena kerusakan hutan semakin parah. Dengan pertimbangan yang matang, pesantren ini tergerak untuk menjadi pioner dalam gerakan penyelamatan hutan.

Sebelum pendirian sekolah kejuruan yang ada sekarang, sebenarnya kami sudah mengawali dengan aksi untuk meminimalisir penggunaan kayu hutan sebagai bahan bangunan rumah dan bagunan-bangunan lain. Langkah praktis ini menginspirasi masyarakat untuk turut serta dalam gerakan pengalihan ketergantungan terhadap kayu hasil hutan. Gerakan ini semakin nyata dan berdampak lebih besar setelah berdirinya sekolah kejuruan yang berorientasi kehutanan di pesantren ini. Pada awal pendirian sekolah, kami memperioritaskan untuk menerima siswa yang berasal dari warga di sekitar pesantren yang masih mengandalkan penopang hidupnya dari hutan. Kemudian secara evolusional, pasca lulus dari sekolah, kami lantas mengusahakan agar mereka segera mendapatkan pekerjaan. Hal ini tidak sulit, sebab sebelumnya memang sudah ada Memorandum of Understanding antara kita (pesantren) dengan pengguna lulusan, baik dari pemerintah maupun swasta, khususnya Perhutani.

Al-Ḥamd li Alläh sampai tahun 2016 ini tercatat lebih dari 500 lulusan telah terdistribusi di pelbagai wilayah Indonesia untuk bekerja di bidang kehutanan dan lingkungan. Tentu, kondisi ini akan memutus mata rantai generasi di kalangan warga yang notabene pekerja jobong dan menggantungkan ekonomi mereka dari hasil hutan dengan cara ilegal. Bisa dipastikan langkah strategis ini berdampak positif terhadap perlindungan dan pelestarian hutan di kawasan Singgahan dan sekitarnya. Siswa-siswa di sini sejak awal sudah dilatih untuk melindungi hutan dari dampak buruk manusia, seperti pembalakan dan perusakan ekosistem yang lain. Oleh karena itu kami juga membekali mereka dengan ilmu bela diri (kanuragan). Aksi ini secara teologis adalah bentuk implementasi dari perintah agama, wa'mur bi al-ma'rüf wanha 'an al-munkar. Sudah menjadi komitmen kami sejak awal dalam pendirian sekolah kejuruan ini, diharapkan akan menyediakan lapangan pekerjaan bagi lulusan, jangan sampai kemudian pasca lulus siswa tidak tersalurkan dalam dunia kerja. Kami takut dikatakan melakukan 
pembohongan publik jika tidak membuktikan bahwa lulusan dari sekolah kejuruan ini tidak bekerja sesuai bidang yang ditekuni. ${ }^{29}$

Dari deskripsi yang disajikan secara ekspalanatoris, penulis bertujuan membangun satu konsepsi ekoteologi yang mewakili fenomena di lapangan melalui aktor utama, Kiai Noer selaku key informan dalam penelitian ini. Menurut penjelasan dari aktor primer, menunjukkan bahwa konsepsi ekoteologi yang terbangun merupakan hasil renungan yang alami oleh subjek terhadap sumber ajaran Islam yang diintegrasikan dengan pengalaman, kemudian dirumuskan menjadi suatu kesadaran umum dan langkah praksis untuk menyelesaikan persoalan hutan yang kondisinya semakin kritis di lingkungan dimana pesantren Walisongo berada. Konsepsi ekoteologi ini kemudian diturunkan pada ranah praksis salah satunya dengan mendirikan sekolah kejuruan yang berorientasi kehutanan, sehingga aspek berkelanjutan (sustainable) dan dampak makronya semakin terlihat. Selain melakukan aksi-aksi lingkungan seperti konservasi, penyelamatan mata air, dan kampanye lingkungan lainnya, Kiai Noer juga secara aktif menanamkan kesadaran ekologis itu kepada santri dan masyarakat sekitar Gomang. Dengan memadukan antara dasar teologi Islam, sains dan kearifan tradisi projeksi ini semakin menuju ke arah yang lebih matang.

\section{Penutup}

Diskursus teologi tentang lingkungan adalah wacana yang selalu menarik meskipun sudah sering dibahas. Selama keberadaan bumi dan alam raya masih terus terancam oleh perkembangan peradaban yang dicapai manusia, maka studi ini akan selalu menemukan landasan epistemologis dan aksiologisnya. Namun, dari sekian banyak studi yang mengulas tema teologi lingkungan, relatif masih sedikit yang melihat pada upaya yang secara alami berkembang di lingkungan pesantren di Indonesia. Kiai Noer yang menjadi subjek dalam studi ini memberi penyegaran atas wacana ekoteologi di Indonesia, bahwa untuk membangun kesadaran dan aksi ekologis, maka Islam dan tradisi bisa saling mengisi, sehingga terwujud citra sebenarnya dari manusia sebagai khalifat Allah di bumi. Upaya yang sederhana dari refleksi terhadap sumber Islam, sains dan kearifan tradisi telah mengantarkan pengasuh pesantren Walisongo ini pada konsep ekoteologis yang ramai dibancangkan oleh akademisi.

${ }^{29}$ Ibid. 
Konsep ekoteologis itu mewujud dalam penelitian ini dengan "kalam rimba" sebagi istilah yang digunakan. "Kalam rimba" merupakan gugusan utuh dari simpul-simpul gagasan yang ditawarkan dan diperjuangkan oleh Kiai Noer sebagai berikut, bahwa: (1) Spiritualitas dan tradisi dapat menyambungkan pribadi Muslim dengan alam melalui proses kontemplasi; (2) Makna khalifah (stewardship) harus dimengerti sebagai landasan untuk mengintegrasikan daya pikir dan pengetahuan yang jamak untuk ragam aksi pelestarian lingkungan; dan (3) Perlu memikirkan implikasi aksi pelestarian lingkungan yang berdampak makro dan berkelanjutan tidak hanya bagi lingkungan sendiri, tapi juga mempunya fungsi pemberdayaan masyarakat. Konsep "Kalam Rimba" Kiai Noer ini paling tidak dapat memantik gerakan-gerakan lingkungan lain berbasis agama yang lebih masif lagi. Eksistensi pesantren yang sangat banyak bisa melahirkan kiai Noer lain yang mendakwakan ekoteologi berbasis laut, gunung, sungai dan sebagainya sesuai dengan kondisi geografis dan kepentingan alam yang ingin diselamatkan di lingkungan tersebut.

\section{Daftar Rujukan}

Abdillah, Mujiono. Fikih Lingkungan: Panduan Spiritual Hidup Berwawasan Lingkungan. Yogyakarta: Akademi Manajemen Perusahaan YKPN, 2005.

al-Qardhawi, Yusuf. Islam Agama Ramab Lingkungan, terj. Abdullah Hakim. Jakarta: Pustaka al-Kautsar, 2002.

Arnez, Monika. "Shifting Notions of Nature and Environmentalism in Indonesian Islam" dalam Barbara Schuler (ed.), Environmental and Climate Change in South and Southeast Asia How are Local Cultures Coping? Leiden: Brill, 2014.

Barbara, Schuler (ed.). Environmental and Climate Change in South and Southeast Asia. London: Brill, 2014.

Chittick, William C. Dunia Imajinal Ibu 'Arabi: Kreativitas Imajinasi dan Persoalan Diversitas Agama, terj. Ahmad Syahid. Surabaya: Risalah Gusti, 2001.

Haleem, M.A.S. Abdel. The Qur'an, 7 (Surah [2]: 30). New York: Oxford University Press, 2004.

http: //pp-walisongo.blogspot.com/p/tentang.html. Diakses pada 20 Juli 2016. 14: 33.

https: //en.wikipedia.org/wiki/Matthew_Fox_(priest). Diakses pada 13 Mei 2016, 10: 52. 
https: //www.marxists.org/reference/archive /spirkin/works/ dialectical-materialism/ch05-s03.html. Diakses 20/05/2015 13: 25.

Jr., Lynn White. "The Historical Roots of Our Ecological Crisis", Science, Vol. 155 (1967), 24.

KH. Noer Nasroh, Wawancara, Tuban 17 Juli 2016.

Khalid, FM. dan O’Brien, J. (eds.). Islam and Ecology. London: Cassell Publisher Ltd., 1994.

Miller, G. Tyler. Reflenish The Earth: A Primer in Human Ecology. Belmnt Calif: Wadsworth, 1972.

Nasr, Seyyed Hossein. Man and Nature: The Spiritual Crisis of Modern Man. London: George Allen dan Unwin, 1976.

Nasr, Seyyed Hossein. Religion and the Order of Nature. New York: Oxford University Press, 1996.

Özdemir, Ibrahim, 1998, "An Islamic Approach to the Environment". Diakses 10 Agustus 2014. http: //home.cogeco.ca/ drheault/ee_readings/Islam/ozdemir.pdf.

Özdemir, Ibrahim. 1998. "An Islamic Approach to the Environment." http: //home.cogeco.ca/ drheault/ee_readings/ Islam/ozdemir.pdf.

Ramadan, Tariq. The Messenger: The Meanings of the Life of Mubammad. London: Penguin Books, 2007.

Sahabuddin (ed.). Ensiklopedi al-Qur'an: Kajian Kosakata, Vol. 2. Jakarta: Lintera Hati, 2007. 